\title{
PENGARUH KOMPETENSI DAN DISIPLIN KERJA TERHADAP KINERJA KARYAWAN PADA PT TELKOM INDONESIA WITEL MEDAN
}

\author{
Astuti Situmorang \\ Kornel Munthe
}

\begin{abstract}
This study aimed to determine the effect of competence and discipline on employee performance provided by the Company PT Telkom Indonesia Witel Medan. PT Telkom Indonesia Witel Medan is the State Owned Enterprises engaged in the field of information and communication as well as service providers and telecommunications networks. Data collected through interviews and questionnaires. The total sample of 76 respondents were taken Proportionate Stratified Random Sampling. The results showed that the competence and discipline positive and significant effect partially on employee performance. Simultaneous test shows that the competence and discipline significant influence on employee performance. The coefficient of determination (R2) of 0.520 suggesting that variations in the performance of employees can be explained by changes in the competence and discipline of work by 52 percent, while 48 percent is explained by other variables not included in this study.
\end{abstract}

Keywords: Competence, Work discipline and employee performance.

\section{Latar Belakang}

\section{PENDAHULUAN}

Era globalisasi menimbulkan persaingan yang ketat diantara perusahaan-perusahaan untuk mendapatkan pangsa pasar. Perusahaan harus menjalankan berbagai usahanya dengan kemampuan yang dimiliki karyawan agar perusahaan dapat memiliki daya saing maupun keunggulan dari para pesaingnya sehingga perusahaan dapat bertahan dalam dunia persaingan yang ketat. Perusahaan tidak akan mencapai tujuan yang diinginkan jika karyawan yang terlibat didalam perusahaan tidak dapat bekerja sama dengan baik.

Pada dasarnya setiap perusahaan yang didirikan mempunyai harapan bahwa kelak di kemudian hari akan mengalami perkembangan yang pesat di dalam lingkup usahanya dan menginginkan terciptanya kinerja yang tinggi. Setiap perusahaan berupaya untuk mendapatkan karyawan yang terlibat dalam kegiatan organisasi/perusahaan dapat memberikan hasil kerja karyawan. Ada beberapa faktor yang berpengaruh pada peningkatan kinerja karyawan antara lain kompetensi dan disiplin kerja. Kompetensi adalah suatu kemampuan untuk melaksanakan atau melakukan suatu pekerjaan atau tugas yang dilandasi atas keterampilan dan pengetahuan serta didukung oleh sikap kerja yang dituntut oleh pekerjaan tersebut. Kompetensi dapat diukur dari, pengetahuan, pemahaman, kemampuan, nilai, sikap dan minat. Disiplin kerja adalah suatu sikap ketaatan pada aturan yang ada pada suatu organisasi/perusahaan. Disiplin dapat di ukur dari kehadiran, ketaatan pada peraturan kerja, ketaatan pada standar kerja, tingkat kewaspadaan tinggi dan bekerja etis. Hilangnya disiplin akan berpengaruh terhadap kinerja karyawan pada perusahaan. Bilamana kedisiplinan tidak dapat ditegakkan maka kemungkinan tujuan yang telah ditetapkan tidak dapat dicapai.

Kinerja karyawan adalah hasil kerja yang dicapai seseorang dalam melaksanakan pekerjaan sesuai dengan tugas dan tanggung jawab yang diberikan kepadanya. Setiap organisasi atau instansi dalam melaksanakan program yang diarahkan selalu berdaya guna untuk mencapai tujuan perusahaan. Suatu pekerjaan terkait dengan pendidikan dan pelatihan 
merupakan kebijakan kompetensi sebagai hasil dari kinerja individu di tempat kerja, dimana sering terjadi bahwa kompetensi harus sebagai atribut dari kelompok atau tim.

Beberapa hasil penelitian terdahulu diantaranya adalah Lubis (2011) menemukan ada pengaruh dan signifikan baik secara simultan maupun parsial antara kompetensi SDM dan kedisiplin terhadap kinerja pegawai pada kantor PT. Perkebunan Sumatera Utara. Zakaria (2011) menemukan adanya pengaruh yang dan tidak signifikan secara simultan maupun parsial dari kompetensi terhadap kinerja karyawan PT PLN (Persero) Distribusi Jawa Barat dan Banten.

Hasil penelitian Saktina (2011) menemukan ada pengaruh positif dan signifikan baik secara simultan maupun parsial antara semangat kerja dan disiplin terhadap kinerja karyawan perum pegadaian Kanwil 1 Medan. Fatimah, Siti dan Fira (2015) menemukan ada pengaruh positif dan signifikan baik secara simultan maupun parsial antara kompetensi SDM terhadap kinerja karyawan pada kantor PT. Perkebunan Nusantara IV Medan.

Telkom Indonesia Witel adalah perusahaan informasi dan komunikasi serta penyedia jasa dan jaringan telekomunikasi secara lengkap di Indonesia. Telkom mengklaim sebagai perusahaan telekomunikasi terbesar di Indonesia. Telkom merupakan salah satu BUMN yang sahamnya saat ini dimiliki oleh Pemerintah Indonesia (51,19\%), Publik (40,21\%) dan sisanya $(8,60 \%)$ dimiliki oleh The Bank of New York dan Investor dalam Negeri.

Kantor PT Telkom Indonesia Witel Medan yang berlokasi di Medan merupakan pusat pengendalian seluruh kegiatan operasional perusahaan dimana para karyawan terdiri dari bagian pemasaran, bagian pelayanan pelanggan dan bagian gangguan. Karyawan yang bekerja pada kantor pusat adalah karyawan manajerial yang memiliki fungsi strategis dan sangat penting. Oleh karena itu diperlukan karyawan yang memiliki kualifikasi tersebut, diperlukan karyawan yang berkompetensi dan disiplin dalam bekerja. Karena hal ini akan menentukan kualitas sumber daya manusia yang akan bekerja pada perusahaan tersebut. Dan kinerja karyawan semakin meningkat. Untuk meningkatkan kinerja karyawan PT Telkom Indonesia Witel Medan dalam rangka untuk mewujudkan hasil kerjanya yang telah ditetapkan oleh perusahaan salah satunya adalah melalui upaya peningkatan kompetensi dan disiplin kerja sehingga kelangsungan hidup perusahaan dapat dipertahankan dan tujuan perusahaan dapat tercapai.

Untuk melihat kinerja karyawan dalam tabel berikut disajikan data pemasangan dan penundaan jaringan baru internet. Adapun jumlah pemasangan jaringan baru internet PT Telkom Indonesia Witel Medan selama 6 bulan periode bulan januari-juli pada tahun 2016 adalah sebagai berikut :

Tabel 1. Pemasangan Jaringan Baru Internet PT Telkom Indonesia Witel

Medan Periode Januari-Juli pada Tahun 2016.

\begin{tabular}{|c|c|c|}
\hline Bulan & Pemasangan Jaringan baru internet & Penundaan Jaringan baru internet \\
\hline Januari & 131 & 69 \\
\hline Februari & 206 & 95 \\
\hline Maret & 256 & 102 \\
\hline April & 332 & 109 \\
\hline Mei & 142 & 87 \\
\hline Juni & 133 & 107 \\
\hline
\end{tabular}

Sumber : PT Telkom Indonesia Witel Medan

Berdasarkan data pada Tabel 1.1 dapat dilihat bahwa PT Telkom Indonesia Witel Medan mengalami kenaikan dan penurunan pemasangan dan penundaan jaringan baru internet tidak 
stabil. Hal ini menunjukkan bahwa untuk mencapai target yang optimal perlu ditingkatkan lagi kompetensi dan disiplin kerja karyawan.

Selanjutnya tabel kinerja karyawan yang diukur dari banyaknya jumlah pelanggan pemasangan jaringan baru internet pada PT. Telkom Indonesia Witel Medan dapat di lihat pada Tabel 2 berikut:

Tabel 2. Pemasangan Jaringan Baru Internet PT Telkom Indonesia Witel Medan Periode Januari-Juli pada Tahun 2016.

\begin{tabular}{|c|c|c|c|c|}
\hline Bulan & $\begin{array}{c}\text { Jumlah Pelanggan Pemasangan } \\
\text { Jaringan Baru Internet }\end{array}$ & Terpasang & $\%$ & Batal Terpasang \% \\
\hline Januari & 212 & 200 & 94,34 & 5,66 \\
\hline Februari & 324 & 301 & 92,90 & 7,10 \\
\hline Maret & 383 & 358 & 93,47 & 6,53 \\
\hline April & 469 & 441 & 94,03 & 5,97 \\
\hline Mei & 252 & 229 & 90,87 & 9,13 \\
\hline Juni & 251 & 240 & 95,62 & 4,38 \\
\hline
\end{tabular}

Sumber : PT Telkom Indonesia Witel Medan

Berdasarkan data pada Tabel 2 dapat diduga batal pemasangan jaringan baru internet dan naik turunnya tingkat kinerja karyawan pada PT Telkom Indonesia Witel Medan salah satu disebabkan oleh kurangnya kompetensi dan kurangnya displin kerja.

Fenomena yang berkaitan dengan kompetensi ini disebabkan oleh kurangnya kemampuan karyawan di bidang pelayanan pelanggan, sehingga banyak karyawan hanya mendapatkan uang transportasi saja dibandingkan dengan karyawan yang mencapai target yang bisa mendapatkan reward sebagai gaji tambahan di luar gaji pokok dari perusahaan. Kurangnya ketegasan dalam berbicara terhadap pelanggan telkom, sehingga karyawan tidak dapat mencapai target yang sudah di tentukan oleh perusahaan. Selain itu karyawan belum bekerja dengan sungguh-sungguh, karyawan hanya mengetahui sebatas pekerjaan mereka saja. Berdasarkan uraian diatas maka dilakukan penelitian dengan judul: "Pengaruh Kompetensi dan Disiplin Kerja Terhadap Kinerja Karyawan pada PT Telkom Indonesia Witel Medan".

\section{Kompetensi}

\section{TINJAUAN PUSTAKA}

Kompetensi adalah suatu kemampuan untuk melaksanakan atau melakukan suatu pekerjaan atau tugas yang dilandasi atas keterampilan dan pengetahuan serta didukung oleh sikap kerja yang dituntut oleh pekerjaan tersebut. Menuruu Wibowo (2007) Kompetensi diartikan sebagai kemampuan untuk melaksanakan atau melakukan suatu pekerjaan atau tugas yang dilandasi oleh keterampilan dan pengetahuan kerja yang dituntut oleh pekerjaan tersebut. Menurut Robbin (2007) bahwa kompetensi adalah "kemampuan (ability) atau kapasitas seseorang untuk mengerjakan berbagai tugas dalam suatu pekerjaan dimana kemampuan ini ditentukan oleh 2 (dua) faktor yaitu kemampuan intelektual dan kemampuan fisik. Secara lebih rinci Spencer dan Spencer dalam Palan (2007) mengemukakan bahwa kompetensi menunjukkan karakteristik yang mendasari perilaku yang menggambarkan motif, karakteristik pribadi (ciri khas), konsep diri, nilai-nilai, pengetahuan atau keahlian yang dibawa seseorang yang berkinerja unggul (superior performer) di tempat kerja.

Ada 5 (lima) karakteristik yang membentuk kompetensi yakni :

1. Faktor pengetahuan yaitu meliputi masalah teknis, administratif, proses kemanusiaan dan sistem. 
2. Keterampilan yaitu merujuk pada kemampuan seseorang untuk melakukan suatu kegiatan.

3. Konsep diri dan nilai-nilai yaitu merujuk pada sikap, nilai-nilai dan citra diri seseorang, seperti kepercayaan seseorang bahwa dia bisa berhasil dalam suatu situasi.

4. Karakteristik pribadi yaitu merujuk pada karakteristik fisik dan konsistensi tanggapan terhadap situasi atau informasi, seperti pengendalian diri dan kemampuan untuk tetap tenang dibawah tekanan.

5. Motif yaitu merupakan emosi, hasrat, kebutuhan psikologis atau dorongan-dorongan lain yang memicu tindakan.

\section{Ciri-ciri Kompetensi}

Kompetensi menurut Sutrisno (2009) merupakan landasan dasar karakteristik orang dan mengindikasikan cara berperilaku atau berpikir menyamakan situasi dan mendukung untuk periode waktu cukup lama.

Ada lima karakteristik kompetensi yaitu sebagai berikut :

1. Motif (Motive) yaitu apa yang secara konsisten dipikirkan atau keinginan- keinginan yang menyebabkan melakukan tindakan. Apa yang mendorong perilaku mengarah dan dipilih terhadap kegiatan atau tujuan tertentu. Contoh: motif berprestasi akan memotivasi orang-orang secara terus menerus untuk merancang tujuan yang cukup menantang serta mengambil tanggung jawab atas pekerjaannya dan menggunakan umpan balik untuk menjadi lebih baik.

2. Sifat/ciri bawaan (Trait) yaitu ciri fisik dan reaksi-reaksi yang bersifat konsisten terhadap situasi atau informasi. Contoh: Reaksi waktu, luas pandangan yang baik merupakan kompetensi bagi seorang pilot.

3. Konsep diri (Self concept) yaitu sikap, nilai atau self image dari orang-orang. Contoh: Percaya diri (self confidence) keyakinan bahwa ia akan efektif dalam berbagai situasi merupakan bagian dari konsep dirinya.

4. Pengetahuan (Knowledge) yaitu suatu informasi yang dimiliki seseorang khususnya pada bidang spesifik. Pengetahuan merupakan kompetensi yang kompleks. Biasanya tes pengetahuan mengukur kemampuan untuk memilih jawaban yang paling benar tetapi tidak bisa melihat apakah seseorang dapat melakukan pekerjaan berdasarkan pengetahuan yang dimilikinya itu.

5. Keterampilan (Skill) yaitu kemampuan untuk mampu melaksanakan tugas-tugas fisik dan mental tertentu. Contohnya: Seorang dokter gigi memiliki kemampuan menambal dan mencabut gigi tanpa merusak syaraf.

\section{Jenis Kompetensi}

Menurut Kunandar (2007) kompetensi dapat dibagi 5 (lima) bagian yakni:

1. Kompetensi intelektual yaitu berbagai perangkat pengetahuan yang ada pada diri individu yang diperlukan untuk menunjang kinerja.

2. Kompetensi fisik yakni perangkat kemampuan fisik yang diperlukan untuk pelaksanaan tugas.

3. Kompetensi pribadi yakni perangkat perilaku yang berkaitan dengan kemampuan individu dalam mewujudkan diri, transformasi diri, identitas diri dan pemahaman diri.

4. Kompetensi social yakni perangkat perilaku tertentu yang merupakan dasar dari pemahaman diri sebagai bagian yang tidak terpisahkan dari lingkungan sosial.

5. Kompetensi spiritual yakni pemahaman, penghayatan serta pengamalan kaidah-kaidah keagamaan.

\section{Manfaat Kompetensi}


Kompetensi sangat diperlukan setiap organisasi terutama untuk meningkatkan kinerja. Menurut Prihadi (2004) manfaat kompetensi adalah:

1. Prediktor kesuksesan kerja. Model kompetensi yang akurat akan dapat menentukan dengan tepat pengetahuan serta ketrampilan apa saja yang dibutuhkan untuk berhasil dalam suatu pekerjaan. Apabila seseorang pemegang posisi mampu memiliki kompetensi yang dipersyaratkan pada posisinya maka ia dapat diprediksikan akan sukses.

2. Merekrut karyawan yang andal. Apabila telah berhasil ditentukan kompetensikompentensi apa saja yang diperlukan suatu posisi tertentu maka dengan mudah dapat dijadikan kriteria dasar dalam rekrutmen karyawan baru.

3. Dasar penilaian dan pengembangan karyawan. Identifikasi kompetensi pekerjaan yang akurat juga dapat dipakai sebagai tolak ukur kemampuan seseorang. Dengan demikian berdasarkan sistem kompetensi ini dapat diketahui apakah seseorang telah bagaimana mengembangkannya, dengan pelatihan dan pembinaan atau perlu dimutasikan kebagian lain.

\section{Indikator Kompetensi}

Wibowo (2007) menjelaskan indikator kompetensi sebagai berikut:

a. Pengetahuan yaitu kesadaran dalam bidang kognitif. Misalnya bagaimana melakukan pembelajaran yang baik sesuai dengan kebutuhan yang ada di perusahaan.

b. Pemahaman yaitu kedalam kognitif. Misalnya seorang karyawan dalam melaksanakan pembelajaran harus mempunyai pemahaman yang baik tentang karakteristik dan kondisi kerja secara efektif dan efisien.

c. Kemampuan yaitu sesuatu yang dimiliki oleh individu untuk melaksanakan tugas atau pekerjaan yang dibebankan kepadanya. Misalnya kemampuan karyawan dalam memilih metode kerja yang dianggap lebih efektif.

d. Nilai yaitu suatu standar perilaku yang telah diyakini dan secara psikologis telah menyatu dalam diri seseorang. Misalnya: kejujuran, keterbukaan.

e. Sikap yaitu perasaan senang-tidak senang, suka-tidak suka, reaksi terhadap suatu rangsangan yang datang dari luar. Misalnya reaksi terhadap krisis ekonomi

f. Minat yaitu kecenderungan seseorang untuk melakukan suatu perbuatan. Misalnya, melakukan suatu aktivitas kerja.

\section{Disiplin Kerja}

Pengertian disiplin dapat dikonotasikan sebagai suatu hukuman, meskipun arti yang sesungguhnya tidaklah demikian. Disiplin berasal dari bahasa latin "Disciplina" yang berarti latihan atau pendidikan kesopanan dan kerohanian serta pengembangan tabiat. Disiplin Kerja adalah kesadaran dan kesediaan seseorang menaati semua peraturan perusahaan dan normanorma sosial yang berlaku (Hasibuan 2012).

Menurut Singodimedjo dalam Sutrisno (2012) mengatakan bahwa disiplin adalah sikap kesediaan dan kerelaan seseorang untuk memahami dan mentaati norma-norma peraturan yang berlaku disekitarnya. Disiplin adalah suatu sikap ketaatan pada aturan yang ada pada suatu organisasi/perusahaan menurut Rivai (2004). Menurut Siagian (2007) disiplin merupakan tindakan manajemen untuk mendorong para anggota memenuhi tuntutan berbagai ketentuan yang harus ditaati dan standar yang harus dipenuhi. Disiplin yang baik mencerminkan besarnya rasa tanggung jawab seseorang terhadap tugas-tugas yang diberikan kepadanya. Hal ini mendorong gairah dan semangat kerja serta terwujudnya tujuan perusahaan, karyawan dan masyarakat.

Berdasarkan beberapa pendapat para ahli di atas dapat disimpulkan bahwa disiplin adalah suatu sikap ketaatan pada aturan yang ada pada suatu organisasi/perusahaan. Sifat ini 
sudah merupakan dasar dari disiplin tanpa memperhatikan baik atau buruknya aturan tersebut. Disiplin tidak ada kaitannya dengan nilai yang akan dicapai oleh suatu aturan. Seorang karyawan harus mengetahui benar atau tidaknya suatu aturan tersebut dalam melaksanakan semua aturan-aturan tersebut dan sadar dengan apa yang dilakukannya. Disiplin juga merupakan suatu hal penting dalam upaya menciptakan keteraturan dalam organisasi.

Kedisiplinan dapat diwujudkan dalam bentuk sikap, tingkah laku, maupun perbuatan yang sesuai dengan peraturan tersebut. Kedisiplinan adalah sebagai suatu sikap, tingkah laku dan perbuatan yang sesuai dengan peraturan dari perusahaan yang tertulis maupun tidak tertulis. Kedisiplinan di dalam prakteknya mengandung pengertian dua unsur yaitu :

a. Unsur positif yaitu sikap di dalam menjalankan tugas oknum bersangkutan ikhlas menerima tugas tersebut dan ikut bertanggung jawab atas penyelesaian dan sukses tugas tersebut.

b. Unsur negatif yaitu disiplin yang mati/tidak berjiwa disiplin yang dipunyai oleh orang yang tidak jujur jiwanya. Bilamana suatu tugas dijalankan oleh orang seperti ini sukar berkembang dan pertanggungjawabannya tidak baik.

\section{Tipe-tipe Disiplin Kerja}

Menurut Mangkunegara (2009) terdapat 3 (tiga) tipe tindakan disiplin yaitu:

1. Disiplin preventif yaitu kegiatan yang mendorong pada karyawan untuk mengikuti berbagai standart dan aturan sehingga penyelewengan dapat dicegah. Sasaran pokok dari kegiatan ini adalah untuk mendorong disiplin diri diantara para karyawan/pegawai. Dengan cara ini para karyawan/pegawai bekerja dengan ikhlas bukan karena paksaan manajemen.

2. Disiplin korektif adalah kegiatan yang diambil untuk menangani pelanggaran yang dilakukan karyawan/pegawai terhadap peraturan yang berlaku dan mencegah terjadinya pelanggaran lebih lanjut. Kegiatan korektif sering berupa bentuk hukuman dan disebut tindakan pendisiplinan. Contohnya dengan tindakan skorsing terhadap karyawan.

3. Disiplin progresif yaitu tindakan memberi hukuman berat terhadap pelanggaran yang berulang. Contoh dari tindakan disiplin progresif antara lain:

a. Teguran secara lisan dan tertulis oleh atasan

b. Skorsing dari pekerjaan selama beberapa hari

c. Diturunkan pangkatnya

d. Dipecat

\section{Indikator Disiplin Kerja} berikut:

Rivai (2004) menjelaskan bahwa, terdapat 5 (lima) indikator disiplin, yaitu sebagai

1. Kehadiran. Hal ini menjadi indikator yang mendasar untuk mengukur kedisiplinan dan biasanya karyawan yang memiliki disiplin kerja rendah terbiasa untuk terlambat dalam bekerja.

2. Ketaatan pada peraturan kerja. Karyawan yang taat pada peraturan kerja tidak akan melalaikan prosedur kerja dan akan selalu mengikuti pedoman kerja yang ditetapkan oleh perusahaan.

3. Ketaatan pada standar kerja. Hal ini dapat dilihat melalui besarnya tanggung jawab karyawan teradap tugas yang diamanahkan kepadanya. 
4. Tingkat kewaspadaan tinggi. Karyawan memiliki kewaspadaan tinggi akan selalu berhatihati, penuh perhitungan dan ketelitian dalam bekerja, serta selalu menggunakan sesuatu secara efektif dan efisien.

5. Bekerja etis. Beberapa karyawan mungkin melakukan tindakan yang tidak sopan ke pelanggan atau terlibat dalam tindakan yang tidak pantas. Hal ini merupakan salah satu bentuk tindakan tidak disiplin, sehingga bekerja etis sebagai salah satu wujud dari disiplin kerja karyawan.

Dalam penelitian ini yang digunakan sebagai acuan dalam pengukuran disiplin menurut Rivai (2004) yaitu : kehadiran, ketaatan pada peraturan kerja, ketaatan pada standar kerja, tingkat kewaspadaan tinggi dan bekerja etis.

\section{Kinerja Karyawan}

Pengertian kinerja merupakan hasil kerja yang dicapai seseorang dalam melaksanakan pekerjaan sesuai dengan tugas dan tanggung jawab yang diberikan kepadanya. Kinerja berasal dari kata job performance atau actual performance yang berarti prestasi kerja atau prestasi sesungguhnya yang dicapai oleh seseorang. Adapun pendapat para ahli mengenai pengertian kinerja sebagai berikut:

Menurut Sutrisno (2009) kinerja merupakan hasil kerja yang dicapai seseorang dalam melaksanakan pekerjaan sesuai dengan tugas dan tanggung jawab yang diberikan kepadanya. Menurut Sedarmayanti (2011) mengungkapkan bahwa: "Kinerja merupakan terjemahan dari performance yang berarti hasil kerja seorang pekerja, sebuah proses manajemen atau suatu organisasi secara keseluruhan dimana hasil kerja tersebut harus dapat ditunjukkan buktinya secara konkrit dan dapat diukur (dibandingkan dengan standar yang telah ditentukan)". Menurut Wibowo (2010) mengemukakan bahwa: "Kinerja adalah tentang melakukan pekerjaan dan hasil yang dicapai dari pekerjaan tersebut".

Berdasarkan pengertian-pengertian di atas dapat dikemukakan bahwa kinerja adalah suatu hasil kerja yang dicapai oleh seorang pegawai sesuai dengan standar dan kriteria yang telah ditetapkan dalam kurun waktu tertentu.

\section{Penilaian Kinerja}

Kinerja merupakan suatu kondisi yang harus diketahui dan dikonfirmasikan kepada pihak tertentu untuk mengetahui tingkat pencapaian hasil suatu instansi dihubungkan dengan visi yang diemban suatu instansi pemerintah serta mengetahui dampak positif dan negatif. Penilaian kinerja pada dasarnya merupakan faktor kunci guna mengembangkan suatu organisasi secara efektif dan efisien karena adanya kebijakan atau program yang lebih baik atas sumber daya manusia yang ada dalam organisasi. Sutrisno (2009) menyatakan bahwa kinerja merupakan hasil upaya seseorang yang ditentukan oleh kemampuan karakteristik pribadinya serta persepsi terhadap perannya dalam pekerjaan itu. Berdasarkan beberapa pengertian di atas maka dapat ditarik kesimpulan bahwa kinerja merupakan hasil kerja yang dicapai seseorang dalam melaksanakan pekerjaan sesuai dengan tugas dan tanggung jawab yang diberikan kepadanya.

Menurut Sedarmayanti (2011) menjelaskan bahwa tujuan penilaian kinerja adalah:

1. Meningkatkan kinerja karyawan dengan cara membantu mereka agar menyadari dan menggunakan seluruh potensi mereka dalam mewujudkan tujuan organisasi.

2. Memberikan informasi kepada karyawan dan pimpinan sebagai dasar untuk mengambil keputusan yang berkaitan dengan pekerjaan.

\section{Manfaat Penilaian Kinerja}


Menurut Umam (2010) mengemukakan bahwa kontribusi hasil penilaian merupakan suatu yang sangat bermanfaat bagi perencanaan kebijakan organisasi. Secara terperinci penilaian kinerja bagi organisasi adalah:

a. Penyesuaian-penyesuaian kompensasi.

b. Perbaikan kinerja.

c. Kebutuhan latihan dan pengembangan.

d. Pengambilan keputusan dalam hal penempatan promosi, mutasi, pemecatan, pemberhentian, dan perencanaan tenaga kerja.

e. Untuk kepentingan penelitian pegawai.

f. Membantu diagnosis terhadap kesalahan desain pegawai.

\section{Indikator-indikator Kinerja}

Menurut Sutrisno (2009) ada enam indikator dari kinerja yakni:

1. Hasil Kerja

Meliputi tingkat kuantitas maupun kualitas yang telah dihasilkan dan sejauh mana pengawasan dilakukan.

2. Pengetahuan Pekerjaan

Tingkat pengetahuan yang terkait dengan tugas pekerjaan yang akan berpengaruh langsung terhadap kuantitas dan kualitas dari hasil kerja.

3. Inisiatif

Tingkat inisiatif selama melaksanakan tugas pekerjaan khususnya dalam hal penanganan masalah-masalah yang timbul.

4. Kecekatan Mental

Tingkat kemampuan dan kecepatan dalam menerima instruksi kerja dan menyesuaikan dengan cara kerja serta situasi kerja yang ada.

5. Sikap

Tingkat semangat kerja serta sikap positif dalam melaksanakan tugas pekerjaan.

6. Disiplin waktu dan absensi

Tingkat ketepatan waktu dan tingkat kehadiran.

Pengaruh Kompetensi Terhadap Kinerja Karyawan.

Kinerja karyawan yang tinggi dapat dicapai jika seluruh karyawan yang ada dalam perusahaan bekerja dengan baik dan mampu menjalankan peranannya sesuai dengan kebutuhan dan keinginan pelanggan. Oleh sebab itu diperlukan dukungan adanya kompetensi guna meningkatkan kinerja karyawan tersebut. Kompetensi dan kinerja yang tinggi memberikan isyarat bahwa perusahaan dikelola dengan baik dan secara fundamental akan menghasilkan perilaku manajemen yang baik. Kompetensi menentukan perusahaan untuk mendapatkan keuntungan. Bila karyawan memandang reward (upah tambahan) tidak memadai maka kinerja karyawan akan menurun. Jika seseorang karyawan menghasilkan kinerja yang diharapkan perusahaan, karyawan akan mendapatkan hasil kerja yang dihasilkan oleh seorang karyawan untuk mencapai tujuan yang diharapkan. Menutur Wibowo (2007) Kompetensi diartikan sebagai kemampuan untuk melaksanakan atau melakukan suatu pekerjaan atau tugas yang dilandasi oleh keterampilan dan pengetahuan kerja yang dituntut oleh pekerjaan tersebut. Pengaruh Disiplin Kerja Terhadap Kinerja Karyawan.

Disiplin Kerja adalah kesadaran dan kesediaan seseorang menaati semua peraturan perusahaan dan norma-norma sosial yang berlaku (Hasibuan 2012). Hilangnya disiplin akan berpengaruh terhadap kinerja karyawan atas tugas/pekerjaan. Bilamana kedisiplinan tidak dapat ditegakkan maka kemungkinan tujuan yang telah ditetapkan tidak dapat dicapai dengan baik. Dengan demikian bahwa adanya disiplin kerja maka kinerja karyawan akan meningkat 
karena para karyawan akan dapat bekerja sama dengan individu lainnya secara maksimal. Begitu juga sebaliknya jika seorang karyawan tidak disiplin atau kedisiplinan menurun maka kinerja karyawan akan turun juga. Jadi dengan kata lain disiplin kerja akan berpengaruh terhadap kinerja karyawan.

\section{Ruang Lingkup Penelitian}

\section{METODE PENELITIAN}

Penelitian ini dilakukan untuk mengetahui pengaruh kompetensi dan disiplin kerja terhadap kinerja karyawan pada PT Telkom Indonesia Witel Medan. Dalam penelitian ini peneliti akan melakukan penelitian pengumpulan data dengan wawancara dan membagikan kuesioner pada PT Telkom Indonesia Witel Medan yang beralamat di Jl. Prof. H. M. Yamin No. 13 Medan.

\section{Populasi dan Sampel}

Populasi dalam penelitian ini adalah seluruh karyawan pada PT Telkom Indonesia Witel Medan tahun 2016 yang berjumlah 317 orang. Dari populasi yang ada ditetapkan jumlah sampel penelitian dan kemudian sampel diambil secara proportionate stratified random sampling dari masing-masing unit kerja yang ada pada PT Telkom Indonesia Witel Medan. Untuk menentukan ukuran sampel penelitian dari populasi tersebut dapat digunakan rumus Slovin (Sunyoto 2013:16) yaitu:

Dimana: $\quad \mathrm{n}=$ Ukuran sampel

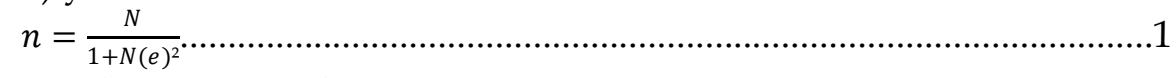

$\mathrm{N}=$ Banyak populasi

$\mathrm{e}^{2}=$ Presisi yang diharapkan $(10 \%)$

Berdasarkan rumus tersebut maka:

$$
\begin{gathered}
n=\frac{317}{1+317(0.1)^{2}} \\
n=76,01 \text { atau dibulatkan } 76 \text { orang. }
\end{gathered}
$$

Jumlah sampel yang diambil sebanyak 76 orang.

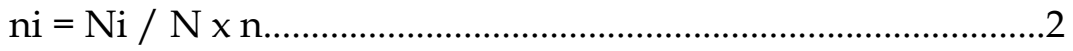

\section{Operasionalisasi Variabel}

Operasionalisasi variabel merupakan batasan pokok pembahasan sesuai dengan permasalahan dan hipotesis penelitian variabel yang akan diteliti.

Tabel 3. Operasionalisasi Variabel.

\begin{tabular}{|l|l|l|l|}
\hline \multicolumn{1}{|c|}{ Variabel } & \multicolumn{1}{|c|}{ Defenisi Operasional } & \multicolumn{1}{|c|}{ Indikator } & Skala \\
\hline Kompetensi & Kompetensi diartikan sebagai & 1. Pengetahuan & Likert \\
$\left(\mathrm{X}_{1}\right)$ & kemampuan untuk & 2. Pemahaman & \\
& melaksanakan atau melakukan & 3. Kemampuan & \\
& Suatu pekerjaan atau tugas yang & 4. Nilai & \\
& $\begin{array}{l}\text { dilandasi oleh keterampilan dan } \\
\text { pengetahuan kerja yang dituntut }\end{array}$ & 5. Sikap & \\
& 6. Minat & \\
& 6leh pekerjaan tersebut. & & \\
\hline
\end{tabular}




\begin{tabular}{|c|c|c|c|}
\hline $\begin{array}{l}\text { Disiplin } \\
\text { Kerja }\left(X_{2}\right)\end{array}$ & $\begin{array}{l}\text { Disiplin adalah suatu sikap } \\
\text { ketaatan pada aturan yang ada } \\
\text { pada } \\
\text { organisasi/perusahaan. } \\
\text { sumber: Rivai (2004) }\end{array}$ & $\begin{array}{ll}\text { 1. Kehadiran } \\
\text { 2. Ketaatan pada } \\
\text { peraturan kerja } \\
\text { 3. Ketaatan pada } \\
\text { standar kerja } \\
\text { 4. Tingkat } \\
\text { kewaspadaan } \\
\text { tinggi } \\
\text { 5. Bekerja etis }\end{array}$ & Likert \\
\hline $\begin{array}{l}\text { Kinerja } \\
\text { Karyawan } \\
(Y)\end{array}$ & $\begin{array}{l}\text { Kinerja merupakan hasil kerja } \\
\text { yang dicapai seseorang dalam } \\
\text { melaksanakan pekerjaan sesuai } \\
\text { dengan tugas dan tanggung } \\
\text { jawab yang diberikan } \\
\text { kepadanya. } \\
\text { sumber: Sutrisno (2009) }\end{array}$ & $\begin{array}{ll}\text { 1. } & \text { Hasil kerja } \\
\text { 2. } & \text { Pengetahuan } \\
\text { Pekerjaan } \\
\text { 3. Inisiatif } \\
\text { 4. Kecekatan } \\
\text { mental } \\
\text { 5. Sikap } \\
\text { 6. Disiplin waktu } \\
\text { dan Absensi }\end{array}$ & Likert \\
\hline
\end{tabular}

Sumber: Diolah Penulis

Skala Pengukuran Variabel

Skala pengukuran yang digunakan untuk mengukur masing-masing variabel adalah dengan menggunakan skala Likert. Menurut Sugiyono (2006) Skala Likert adalah suatu alat ukur yang digunakan untuk mengukur sikap, pendapat dan persepsi seseorang atau sekelompok orang tentang fenomena sosial.

Tabel 4. Instrumen Skala Likert.

\begin{tabular}{|l|l|c|}
\hline No & \multicolumn{1}{|c|}{ Pernyataan } & Skor \\
\hline 1 & Sangat Setuju (SS) & 5 \\
\hline 2 & Setuju (S) & 4 \\
\hline 3 & Cukup Setuju (CS) & 3 \\
\hline 4 & Tidak Setuju (TS) & 1 \\
\hline 5 & Sangat Tidak Setuju (STS) & 2 \\
\hline
\end{tabular}

\section{Sumber: Diolah Penulis}

\section{Teknik Pengumpulan Data}

Jenis data yang digunakan dalam penelitian ini adalah:

1. Kuesioner

Teknik pengumpulan data dengan kuesioner merupakan satu teknik pengumpulan data dengan memberikan daftar pernyataan kepada responden, dengan harapan responden memberikan respon terhadap pernyataan yang ada pada kuesioner. Dalam kuesioner ini nantinya akan digunakan model pernyataan tertutup, yakni bentuk pernyataan yang sudah disertai alternatif jawaban sebelumnya sehingga responden dapat memilih salah satu dari alternatif jawaban tersebut.

2. Wawancara

Teknik pengumpulan data dengan wawancara merupakan teknik pengumpulan data dengan cara menggunakan pertanyaan lisan kepada subjek penelitian. Hal ini dilakukan 
untuk mendapatkan gambaran dari permasalahan yang biasanya terjadi karena sebab-sebab khusus yang tidak dapat dijelaskan dengan kuesioner.

\section{Teknik Analisis Data} metode:

Kumpulan data yang sudah diperoleh kemudian dianalisis dengan menggunakan

\section{Uji Validitas dan Reliabilitas}

Menurut Sugiyono (2008) "valid berarti instrumen tersebut dapat digunakan untuk mengukur apa yang seharusnya diukur". Dalam hal ini teknik korelasi untuk menentukan validitas item ini sampai sekarang merupakan teknik yang paling banyak digunakan. Selanjutnya dalam memberikan interpretasi terhadap koefisien korelasi dimana item yang mempunyai korelasi positif dengan kriteria (skor total) serta korelasi yang tinggi menunjukkan bahwa item tersebut mempunyai validitas yang tinggi pula. Menurut Sugiyono (2008) syarat minimum dianggap memenuhi syarat kalau nilai $r=0,30$ ". Jika nilai korelasi antara butir dengan skor total kurang dari 0,30 maka butir dalam instrumen tersebut dinyatakan tidak valid.

Uji reliabilitas digunakan untuk menguji apakah hasil kuesioner dapat dipercaya atau tidak. Menurut Sugiyono (2008) "pengujian reliabilitas dengan internal consistency dilakukan dengan cara mencoba instrumen sekali saja kemudian data yang diperoleh dianalisis dengan teknik tertentu". Pengujian reliabilitas instrumen dengan belah dua arah Spearmen Brown dengan rumus:

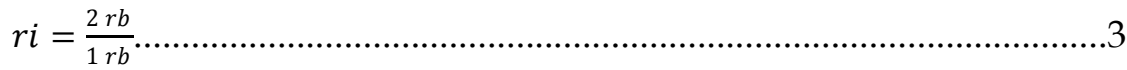

Dimana :

$r i=$ Reliabilitas internal seluruh instrumen

$\mathrm{rb}=$ Korelasi product moment antara belahan pertama dan kedua

Perhitungan reliabilitas pada penelitian ini menggunakan analisis yang dikembangkan oleh Alpha Cronbach. Kriterianya sebagai berikut :

$a \geq 0,50$ artinya instrumen reliabel.

$a<0,50$ artinya instrumen tidak reliabel.

Perhitungan pengujian reliabilitas juga dilakukan dengan bantuan komputer menggunakan SPSS (Statistical Program for Social Sciences) versi 20.

\section{Persamaan Regresi Linear Berganda}

Teknik analisis yang digunakan adalah persamaan regresi linear berganda yang berguna untuk mengetahui pengaruh kompetensi $\left(X_{1}\right)$ dan disiplin kerja $\left(X_{2}\right)$ terhadap kinerja karyawan (Y) (Sugiyono 2008) model persamaan yang digunakan dengan rumus:

$$
\mathbf{Y}=\mathbf{a}+\mathbf{b}_{1} \mathbf{X}_{1}+\mathbf{b}_{2} \mathbf{X}_{2}+\mathbf{e i}
$$

Dari persamaan diatas diaplikasikan pada penelitian ini sebagai berikut:

Keterangan :

$$
\begin{array}{ll}
\mathrm{Y} & =\text { Kinerja Karyawan } \\
\mathrm{X}_{1} & =\text { Kompetensi } \\
\mathrm{X}_{2} & =\text { Disiplin Kerja } \\
\mathrm{b}_{1} & =\text { Koefisien variable Kompetensi } \\
\mathrm{b}_{2} & =\text { Koefisien variable Disiplin Kerja } \\
\mathrm{a} & =\text { Konstanta } \\
\mathrm{ei} & =\text { Tingkat kesalahan estimasi }
\end{array}
$$

Pengujian model regresi linear berganda ini digunakan untuk mengetahui pengaruh positif atau negatif dari masing-masing variabel bebas $\left(\mathrm{X}_{1}\right.$ dan $\left.\mathrm{X}_{2}\right)$ terhadap variabel terikat $(\mathrm{Y})$. Uji hipotesis 
Uji hipotesis dilakukan dengan menggunakan uji $\mathrm{F}$ dan uji $\mathrm{t}$ dengan prosedur pengujian sebagai berikut:

\section{HASIL PENELITIAN DAN PEMBAHASAN Hasil Penelitian}

Identitas responden dalam penelitian ini adalah jenis kelamin, status, usia, pendidikan terakhir dan lama bekerja disajikan pada tabel berikut ini :

Tabel 5. Jenis Kelamin Responden

\begin{tabular}{|l|c|c|}
\hline \multicolumn{1}{|c|}{ Jenis Kelamin } & Jumlah & Persentase (\%) \\
\hline Pria & 23 & $30 \%$ \\
\hline Wanita & 53 & $70 \%$ \\
\hline Jumlah & 76 & 100 \\
\hline
\end{tabular}

Sumber : Data diolah dari lampiran 2

Dari data pada Tabel 5 ditunjukkan jenis kelamin responden yang dijadikan sebagai sampel penelitian adalah laki-laki berjumlah 23 orang (30\%) dan perempuan berjumlah 53 Orang (70\%) dari total responden.

Tabel 6. Status Responden

\begin{tabular}{|l|c|c|}
\hline \multicolumn{1}{|c|}{ Status } & Jumlah & Persentase (\%) \\
\hline Belum Menikah & 56 & $74 \%$ \\
\hline Menikah & 20 & $26 \%$ \\
\hline Jumlah & 76 & 100 \\
\hline
\end{tabular}

Sumber : Data diolah dari lampiran 2

Dari data pada Tabel 6 ditunjukkan status responden yang dijadikan sebagai sampel penelitian adalah belum menikah berjumlah 56 orang (74\%) dan menikah berjumlah 20 orang (26\%) dari total responden.

Tabel 7. Usia Responden

\begin{tabular}{|l|c|c|}
\hline \multicolumn{1}{|c|}{ Usia } & Jumlah & Persentase (\%) \\
\hline Dibawah 25 Tahun & 28 & $37 \%$ \\
\hline 26-30 Tahun & 12 & $16 \%$ \\
\hline 31-35 Tahun & 20 & $26 \%$ \\
\hline 36-40 Tahun & 10 & $13 \%$ \\
\hline$>41$ Tahun & 6 & $8 \%$ \\
\hline Jumlah & 76 & 100 \\
\hline
\end{tabular}

Sumber : Data diolah dari lampiran 2

Dari data pada Tabel 7 ditunjukkan usia responden yang dijadikan sebagai sampel penelitian adalah dibawah 25 tahun berjumlah 28 orang (37\%), 26-30 Tahun berjumlah 12 orang (16\%), 31-35 Tahun berjumlah 20 orang (26\%), 36-40 Tahun berjumlah 10 orang (13\%) dan menikah berjumlah 6 orang $(8 \%)$ dari total responden.

Tabel 8. Pendidikan Terakhir Responden

\begin{tabular}{|l|c|c|}
\hline \multicolumn{1}{|c|}{ Pendidikan Terakhir } & Jumlah & Persentase (\%) \\
\hline SMA/SMK & 17 & $22 \%$ \\
\hline Akademi/Diploma & 13 & $17 \%$ \\
\hline S1 & 40 & $53 \%$ \\
\hline S2 & 6 & $8 \%$ \\
\hline Jumlah & 76 & 100 \\
\hline
\end{tabular}


Sumber : Data diolah dari lampiran 2

Dari data pada Tabel 8 ditunjukkan pendidikan terakhir responden yang dijadikan sebagai sampel penelitian adalah SMA/SMK berjumlah 17 orang (22\%), akademi/diploma berjumlah 13 orang (17\%), S1 berjumlah 40 orang (53\%) dan S2 berjumlah 6 orang (8\%) dari total responden.

Tabel 9. Lama Bekerja Responden

\begin{tabular}{|l|c|c|}
\hline \multicolumn{1}{|c|}{ Lama Bekerja } & Jumlah & Persentase (\%) \\
\hline$<2$ Tahun & 37 & $49 \%$ \\
\hline 2 - 5 Tahun & 16 & $21 \%$ \\
\hline 5 - 10 Tahun & 15 & $20 \%$ \\
\hline$>10$ Tahun & 8 & $11 \%$ \\
\hline Jumlah & 76 & 100 \\
\hline
\end{tabular}

Sumber : Data diolah dari lampiran 2

Dari data pada Tabel 9 ditunjukkan lama bekerja responden yang dijadikan sebagai sampel penelitian adalah $<2$ Tahun berjumlah3 7 orang (49\%), 2 - 5 Tahun berjumlah 16 orang (21\%), 5 - 10 Tahun berjumlah 15 orang (20\%) dan $>10$ Tahun berjumlah 8 orang (11\%) dari total responden.

\section{Hasil Uji Validitas Dan Reliabilitas Secara Simultan}

Hasil uji validitas dan reliabilitas disajikan berikut ini:

Tabel 10. Item-Total Statistics

\begin{tabular}{|c|c|c|c|c|}
\hline Indikator Pengukuran & $\begin{array}{c}\text { Scale } \\
\text { Mean if } \\
\text { Item } \\
\text { Deleted } \\
\end{array}$ & $\begin{array}{c}\text { Scale } \\
\text { Variance } \\
\text { if Item } \\
\text { Deleted }\end{array}$ & $\begin{array}{c}\text { Corrected } \\
\text { Item-Total } \\
\text { Correlation }\end{array}$ & $\begin{array}{l}\text { Cronbach's } \\
\text { Alpha if } \\
\text { Item Deleted }\end{array}$ \\
\hline Pengetahuan & 68,63 & 53,964 & 621 & ,920 \\
\hline Pemahaman & 68,40 & 56,248 &, 505 & ,923 \\
\hline Kemampuan & 68,70 & 55,045 & 474 & ,925 \\
\hline Nilai & 68,63 & 54,723 & ,715 & ,918 \\
\hline Sikap & 68,57 & 57,495 & ,328 & ,928 \\
\hline Minat & 68,70 & 51,252 & ,734 & 917 \\
\hline Kehadiran & 68,63 & 54,585 & 607 & ,921 \\
\hline $\begin{array}{l}\text { Ketaatan_pada_Peraturan_Ke } \\
\text { rja }\end{array}$ & 68,53 & 57,085 & ,398 & ,926 \\
\hline $\begin{array}{l}\text { Ketaatan_pada_Standar_Kerj } \\
\text { a }\end{array}$ & 68,37 & 55,137 & ,696 & ,919 \\
\hline $\begin{array}{l}\text { Tingkat_Kewaspadaan_Tingg } \\
\text { i }\end{array}$ & 68,47 & 51,913 & ,870 & ,914 \\
\hline Bekerja_Etis & 68,40 & 56,662 &, 416 & ,925 \\
\hline Hasil_Kerja & 68,37 & 52,930 & ,804 & ,916 \\
\hline Pengetahuan_Pekerjaan & 68,50 & 54,259 & ,694 & ,919 \\
\hline Inisiatif & 68,47 & 53,361 & ,719 & ,918 \\
\hline Kecekatan_Mental & 68,37 & 55,413 & ,594 & 921 \\
\hline Sikap & 68,47 & 55,361 & 698 & ,919 \\
\hline
\end{tabular}




\begin{tabular}{|l|r|r|r|r|}
\hline Disiplin_Waktu_dan_Absensi & 68,60 & 52,593 &, 795 &, 916 \\
\hline
\end{tabular}

Sumber : Data diolah dengan SPSS

Dari Tabel 10 diketahui bahwa ketujuh belas pernyataan penelitian pada PT Telkom Indonesia Witel Medan secara rata-rata sudah valid, karena nilai $\mathrm{r}$ hitung $>0,30$.

a. Hasil Uji Validitas dan Reliabilitas Secara Parsial

Hasil uji reliabilitas variabel Kompetensi disajikan berikut ini :

Tabel 11. Item-Total Statistics

\begin{tabular}{|l|r|r|r|r|}
\hline $\begin{array}{c}\text { Indikator } \\
\text { Pengukuran }\end{array}$ & $\begin{array}{c}\text { Scale Mean if } \\
\text { Item Deleted }\end{array}$ & $\begin{array}{c}\text { Scale Variance if } \\
\text { Item Deleted }\end{array}$ & $\begin{array}{c}\text { Corrected Item- } \\
\text { Total } \\
\text { Correlation }\end{array}$ & $\begin{array}{c}\text { Cronbach's } \\
\text { Alpha if Item } \\
\text { Deleted }\end{array}$ \\
\hline Pengetahuan & 21,00 & 5,931 &, 512 &, 697 \\
Pemahaman & 20,77 & 6,599 &, 428 &, 735 \\
Kemampuan & 21,07 & 5,995 &, 608 &, 721 \\
Nilai & 21,00 & 6,207 &, 322 &, 680 \\
Sikap & 20,93 & 6,754 &, 618 &, 662 \\
Minat & 21,07 & 5,099 & & \\
\hline
\end{tabular}

Sumber : Data diolah dengan SPSS

Dari Tabel 4.14 diketahui bahwa keenam pernyataan penelitian pada PT Telkom Indonesia Witel Medan sudah valid, karena $\mathrm{r}$ hitung > 0,30.

Hasil uji reliabilitas variabel Disiplin Kerja disajikan berikut ini :

Tbel 12. Item-Total Statistics

\begin{tabular}{|l|r|r|r|r|}
\hline \multicolumn{1}{|c|}{ Indikator Pengukuran } & $\begin{array}{c}\text { Scale Mean } \\
\text { if Item } \\
\text { Deleted } \\
\text { Variance if } \\
\text { Item Deleted }\end{array}$ & $\begin{array}{c}\text { Scale } \\
\text { Item-Total } \\
\text { Correlation }\end{array}$ & $\begin{array}{c}\text { Cronbach's } \\
\text { Alpha if Item } \\
\text { Deleted }\end{array}$ \\
\hline Kehadiran & 17,43 & 3,426 &, 662 &, 674 \\
Ketaatan_pada_Peraturan_Kerja & 17,33 & 4,092 \\
Ketaatan_pada_Standar_Kerja & 17,17 & 4,144 &, 502 &, 756 \\
Tingkat_Kewaspadaan_Tinggi & 17,27 & 3,306 &, 702 &, 657 \\
Bekerja_Etis & 17,20 & 4,097 &, 771 \\
\hline
\end{tabular}

Sumber : Data diolah dengan SPSS

Dari Tabel 12 diketahui bahwa kelima pernyataan penelitian pada PT Telkom Indonesia Witel Medan sudah valid, karena nilai $\mathrm{r}$ hitung $>0,30$..

Hasil uji reliabilitas variabel Kinerja Karyawan disajikan berikut ini :

Tabel 13. Item-Total Statistics

\begin{tabular}{|l|r|r|r|r|}
\hline \multicolumn{1}{|c|}{ Indikator Pengukuran } & $\begin{array}{c}\text { Scale Mean } \\
\text { if Item } \\
\text { Deleted }\end{array}$ & $\begin{array}{c}\text { Scale } \\
\text { Variance if } \\
\text { Item Deleted }\end{array}$ & $\begin{array}{c}\text { Corrected } \\
\text { Item-Total } \\
\text { Correlation }\end{array}$ & $\begin{array}{c}\text { Cronbach's } \\
\text { Alpha if Item } \\
\text { Deleted }\end{array}$ \\
\hline Hasil_Kerja & 21,60 & 6,524 &, 799 &, 842 \\
Pengetahuan_Pekerjaan & 21,73 \\
Inisiatif & 21,70 & 7,099 &, 644 &, 868 \\
Kecekatan_Mental & 21,60 & 6,769 &, 640 &, 869 \\
Sikap & 21,70 & 7,214 &, 644 &, 869 \\
Disiplin_Waktu_dan_Absensi & 21,83 & 7,528 &, 758 &, 849 \\
\hline
\end{tabular}


Sumber : Data diolah dengan SPSS

Dari data pada Tabel 4.20 diketahui bahwa keenam pernyataan penelitian pada PT Telkom Indonesia Witel Medan secara rata-rata sudah valid, karena nilai $\mathrm{r}$ hitung $>0,30$.

\section{b. Pengujian Hipotesis}

Uji simultan dilakukan untuk melihat secara simultan pengaruh antara kompetensi dan disiplin kerja terhadap variabel kinerja karyawan. Hasilnya disajikan sebagai berikut:

Tabel 14. ANOVA Uji F

\begin{tabular}{|c|c|c|c|c|c|c|}
\hline \multicolumn{7}{|c|}{ ANOVAa $^{a}$} \\
\hline & & Sum of Squares & Df & Mean Square & $\mathrm{F}$ & Sig. \\
\hline \multirow{3}{*}{1} & Regression & 415,364 & 2 & 207,682 & 39,531 &, $000^{\mathrm{b}}$ \\
\hline & Residual & 383,517 & 73 & 5,254 & & \\
\hline & Total & 798,882 & 75 & & & \\
\hline
\end{tabular}

a. Dependent Variable: Kinerja_Karyawan

b. Predictors: (Constant), Disiplin_Kerja, Kompetensi

Sumber : Data diolah dengan SPSS

Dari Tabel 4.21 di atas nampak bahwa $F_{\text {hitung }}$ sebesar 39,531 > $F_{\text {tabel }}$ sebesar 3,12 atau probabilitas dibawah 5 persen, sehingga dapat disimpulkan bahwa secara simultan variabel kompetensi dan disiplin kerja berpengaruh signifikan terhadap kinerja karyawan pada PT Telkom Indonesia Witel Medan.

c. Uji Parsial (Uji t)

Uji t dilakukan untuk mengetahui pengaruh secara parsial antara variabel kompetensi dan disiplin kerja terhadap variabel kinerja karyawan yang hasilnya dapat dilihat tabel 15 berikut ini:

Tabel 15. Coefficients Uji $t$

Coefficients ${ }^{a}$

\begin{tabular}{|rl|r|r|r|r|r|}
\hline \multirow{2}{*}{ Model } & \multicolumn{2}{|c|}{$\begin{array}{c}\text { Unstandardized } \\
\text { Coefficients }\end{array}$} & $\begin{array}{c}\text { Standardized } \\
\text { Coefficients }\end{array}$ & \multirow{2}{*}{$\mathrm{t}$} & \multirow{2}{*}{ Sig. } \\
\cline { 3 - 5 } & & B & Std. Error & Beta & & \\
\hline \multirow{2}{*}{1} & (Constant) & 2,132 & 2,584 & &, 812 \\
& Kompetensi &, 400 &, 124 &, 351 & 3,231 &, 002 \\
& Disiplin_Kerja &, 600 &, 148 &, 439 & 4,043 &, 000 \\
\hline
\end{tabular}

a. Dependent Variable: Kinerja_Karyawan

Sumber : Data diolah dengan SPSS

Dari Tabel 4.22 di atas nampak bahwa untuk variabel kompetensi nilai $t_{\text {hitung }}>t_{\text {tabel }}$ $(3,231>1.993)$ atau probabilitas dibawah 5 persen, sehingga kompetensi berpengaruh positif dan signifikan terhadap kinerja karyawan. Untuk variabel disiplin kerja nilai $t_{\text {hitung }}>t_{\text {tabel }}$ $(4,043>1.993)$ atau probabilitas dibawah 5 persen, sehingga disiplin kerja berpengaruh positif dan signifikan terhadap kinerja karyawan.

\section{d. Koefisien Determinasi $\left(R^{2}\right)$}

Koefisien determinan (R Square) berguna untuk mengetahui sejauh mana variasi variabel kinerja karyawan dapat dijelaskan oleh variabel kompetensi dan disiplin kerja. Hasil penelitian disajikan pada Tabel 16 berikut:

Tabel 4.23. R Square

\section{Model Summary}

\begin{tabular}{|l|r|r|r|r|}
\hline Model & \multicolumn{1}{|c|}{$\mathrm{R}$} & R Square & \multicolumn{1}{c|}{$\begin{array}{c}\text { Adjusted R } \\
\text { Square }\end{array}$} & $\begin{array}{c}\text { Std. Error of the } \\
\text { Estimate }\end{array}$ \\
\hline 1 &, $721^{\mathrm{a}}$ &, 520 &, 507 & 2,292 \\
\hline
\end{tabular}


a. Predictors: (Constant), Disiplin_Kerja, Kompetensi

Sumber: data diolah dengan SPSS

Berdasarkan tabel 4.23 dapat dilihat : koefisien determinan (R Square) adalah sebesar 0,520 Artinya 52\%. Bahwa variasi kinerja karyawan dapat dijelaskan oleh variasi kompetensi dan disiplin kerja sebesar 52\% sisanya 48\%, dijelaskan oleh variabel lain. yang tidak termasuk dalam penelitian ini.

\section{Pengaruh Kompetensi terhadap Kinerja Karyawan}

\section{PEMBAHASAN}

Dilihat dari koefisien regresinya diketahui bahwa $t_{\text {hitung }}$ untuk variabel kompetensi adalah sebesar 3,231 sedangkan nilai $t_{\text {tabel }}$ adalah sebesar 1.993 sehingga 3,231>1.993. Selain itu untuk nilai signifikansinya $(0,002<0,05)$ dengan memperhatikan nilai $t_{\text {tabel }}$ (dua arah) maka $\mathrm{H}_{\mathrm{a}}$ diterima dan $\mathrm{H}_{0}$ ditolak. Dengan ditolaknya Ho berarti kompetensi berpengaruh positif dan signifikan terhadap kinerja karyawan pada PT Telkom Indonesia Witel Medan. Dapat dilihat dari hasil uji validitas secara parsial pada variabel kompetensi dari hasil pembagian kuesioner variabel kompetensi dengan indikator pengetahuan, pemahaman, kemampuan, nilai, sikap dan minat mampu meningkatkan kinerja karyawan. Maka Jika ada perubahan dari setiap indikator kompetensi akan berdampak terhadap kinerja karyawan.

Berdasarkan penelitian terdahulu penelitian ini hasil penelitiannya sama dengan hasil penelitian menurut Fatimah, Siti dan Fira (2015) menemukan ada pengaruh positif dan signifikan baik secara simultan maupun parsial antara kompetensi SDM terhadap kinerja karyawan pada kantor PT Perkebunan Nusantara IV Medan.

\section{Pengaruh Disiplin Kerja terhadap Kinerja Karyawan.}

Dilihat dari koefisien regresinya diketahui bahwa $t_{\text {hitung }}$ untuk variabel Disiplin Kerja adalah 4,043 dengan tingkat signifikan 0,000 dengan nilai $t_{\text {tabel }}$ pada alpha $5 \% \mathrm{dfl}=73$ adalah 1,993. Variabel kompetensi berpengaruh signifikan terhadap kinerja karyawan PT Telkom Indonesia Witel Medan terlihat dari nilai signifikan $0,000<0,05$ nilai $t_{\text {hitung }}(4,043)>t_{\text {tabel }} 1,993$. Dapat dilihat dari hasil uji validitas secara parsial hasil pembagian kuesioner variabel disiplin kerja setiap indikator disiplin kerja seperti kehadiran, ketaatan pada peraturan kerja, ketaatan pada standar kerja, tingkat kewaspadaan tinggi dan bekerja etis mampu meningkatkan kinerja karyawan. Maka jika ada perubahan dari setiap indikator disiplin kerja akan berdampak terhadap kinerja karyawan.

Berdasarkan penelitian terdahulu penelitian ini sama hasil penelitiannya dengan hasil penelitian Saktina (2011) menemukan ada pengaruh positif dan signifikan baik secara simultan maupun parsial antara semangat kerja dan disiplin terhadap kinerja karyawan perum pegadaian Kanwil 1 Medan.

\section{Pengaruh Kompetensi dan Disiplin Kerja terhadap Kinerja}

Dilihat dari koefisien regresinya diketahui bahwa secara simultan terdapat pengaruh positif dan signifikan antar variabel kompetensi dan disiplin kerja terhadap variabel kinerja karyawan. Pengaruh tersebut ditunjukkan pada nilai $F_{\text {hitung }}$ sebesar 39,531 $>F_{\text {tabel }}$ sebesar 3,12 sehingga dapat disimpulkan bahwa secara simultan variabel kompetensi dan disiplin kerja mempengaruhi kinerja karyawan pada PT Telkom Indonesia Witel Medan. Artinya kompetensi dan disiplin kerja mempunyai keeratan hubungan dengan kinerja karyawan dilihat dari indikator kompetensi seperti pengetahuan, pemahaman, kemampuan, nilai, sikap dan minat telah memberi pengaruh yang besar dalam meningkatkan kinerja karyawan, begitu juga dilihat dari setiap indikator disiplin kerja seperti kehadiran, ketaatan pada peraturan kerja, ketaatan pada standar kerja, tingkat kewaspadaan tinggi dan bekerja etis telah memberi pengaruh yang 
besar terhadap kinerja karyawan. Maka setiap kenaikan skor variabel kompetensi menyebabkan kenaikan terhadap kinerja karyawan dan kenaikan satu skor variabel disiplin kerja maka kinerja karyawan juga akan meningkat. Sehingga semakin sesuai kompetensi dan semakin tepat disiplin kerja, maka semakin tinggi kinerja karyawan.

\section{Kesimpulan}

\section{KESIMPULAN DAN SARAN} berikut :

Berdasarkan analisis dan hasil pembahasan dapat dirumuskan kesimpulan sebagai

1. Kompetensi dan disiplin kerja berpengaruh positif terhadap kinerja karyawan pada PT Telkom Indonesia Witel Medan.

2. Kompetensi dan disiplin kerja secara simultan berpengaruh signifikan terhadap kinerja karyawan pada PT Telkom Indonesia Witel Medan

3. Kompetensi dan disiplin kerja secara parsial berpengaruh positif dan signifikan terhadap kinerja karyawan pada PT Telkom Indonesia Witel Medan.

4. Variabel kinerja karyawan mampu dijelaskan oleh variasi variabel kompetensi dan disiplin kerja sebesar $52 \%$ dan sisanya $48 \%$ oleh variabel lain.

\section{Saran}

Berdasarkan kesimpulan diatas maka saran yang dapat penulis ajukan adalah sebagai berikut :

1. Sebaiknya PT Telkom Indonesia Witel Medan meningkatkan pemahaman dan kompetensi yang dimiliki oleh karyawan dan semakin mengembangkan setiap indikator kompetensi dalam menjalankan kemampuannya agar semakin meningkatkan kinerja karyawan.

2. Sebaiknya PT Telkom Indonesia Witel Medan meningkatkan ketepatan waktu dan disiplin kerja dalam perusahaan dan semakin mengembangkan setiap indikator disiplin kerja agar lebih meningkatkan kinerja karyawan.

3. Sebaiknya pimpinan perusahaaan harus lebih meningkatkan pemahaman dan ketepatan waktu serta menjalin hubungan yang baik kepada para karyawan, agar mendorong para karyawan untuk mengerjakan tugas sehingga akan tercapai tujuan perusahaan. Perilaku pemimpin perlu lebih ditingkatkan karena, pemimpin memiliki pengaruh signifikan terhadap kinerja karyawan.

4. Bagi peneliti selanjutnya diharapkan untuk dapat meneruskan dan mengembangkan penelitian pada masa yang akan datang, melalui penelitian yang lebih mendalam tentang faktor-faktor lain yang mempengaruhi kinerja karyawan.

\section{DAFTAR PUSTAKA}

Fatimah, Siti dan Fira. 2015. Pengaruh Kompetensi SDM terhadap Kinerja. Skripsi. Medan: Program Sarjana Fakultas Ekonomi Universitas Sumatera Utara.

Hasibuan, Malayu. 2012. Manajemen Sumber Daya Manusia. Edisi Revisi : PT.Bumi Aksara, Jakarta

Kunandar. 2007. Guru Profesional. Edisi Revisi, Jakarta: Rajawali.Pers.

Lubis. 2011. Pengaruh Kompetensi SDM dan Kedisiplin terhadap Kinerja Pegawai. Skripsi. Medan: Program Sarjana Fakultas Ekonomi Universitas Sumatera Utara.

Mangkunegara, AA, Anwar Prabu. 2009. Evaluasi Kinerja SDM. Bandung: PT Refika Aditama

Prihadi, S. 2004. Kinerja, Aspek Pengukuran. Penerbit : PT. Gramedia Pustaka, Jakarta 
Rivai, Veithzal. 2004. Kepemimpinan Dan Perilaku Organisasi. Jakarta : Raja Grafindo Persada

Robbins \& Coulter. 2007. Manajemen. Jakarta : Indeks.

Saktina. 2011. Pengaruh Semangat Kerja dan Disiplin terhadap Kinerja Karyawan. Skripsi. Medan: Program Sarjana Fakultas Ekonomi Universitas Sumatera Utara.

Sedarmayanti dan Hidayat, Syarifudin. 2011. Metodologi Penelitian. Bandung : Mandar Maju

Sekaran, Uma. 2006. Research Methods for Business Buku2. Edisi 4. Salemba Empat. Jakarta.

Siagian, Sondang P. 2007. Manajemen Sumber Daya Manusia, Edisi pertama, Cetakan ke Empat belas, Penerbit Bumi Aksara: Jakarta.

Spencer, M. Lyle and Spencer,M.Signe. 2007. Competence at Work:Models for Superrior. John Wiley \& Son, Canada.

Sugiyono. 2006. Statistika Untuk Penelitian, Cetakan Ketujuh, Bandung: CV. . 2008. Statistika Untuk Penelitian. Bandung: Alfabeta.

Sunyoto, Danang. 2013. Teori, Kuesioner dan Proses Analisis Data Perilaku Organisasi. CAPS, Yogyakarta.

Sutrisno. 2009. Manajemen Sumber Daya Manusia, Edisi pertama, Cetakan Pertama, Penerbit Kencana, Jakarta.

Umam, Khaerul 2010. Perilaku Organisasi. Bandung : Pustaka Setia.

Wibowo. 2007. Manajemen Kinerja. Jakarta: PT. Raja Grafindo Persada. . 2010. Manajemen Kinerja. Jakarta: PT. Raja Grafindo Persada.

Zakaria. 2011. Pengaruh Kompetensi Terhadap Kinerja Karyawan. Skripsi. Jawa Barat : Program Sarjana Fakultas Ekonomi Universitas Telkom. 